\title{
GLOBALIZATION AND ITS EFFECTS ON INDIAN AGRICULTURE SECTOR
}

\author{
Radhika Mohta \\ Third Year, Bachelor's of Science in Economics, NMIMS, Mumbai \\ DOI: 10.46609/IJSSER.2020.v05i07.019 URL: https://doi.org/10.46609/IJSSER.2020.v05i07.019
}

\begin{abstract}
The Agriculture sector of India is the most important part of its Economy. It accounts for $18 \%$ percent of the Indian GDP and employs around 50\% of the total workforce of India. Looking at the Economy from 1980s till now, a lot has changed in the agricultural sector. Even though, since 1991 reforms, Globalization has led to Increase in the FDI and productivity of the crops in the sector and also has replaced the conventional methods of farming with the efficient ones, it has also led to an Unequal competition, Marginalization of different sections of the rural India, Alleviation of poverty etc.
\end{abstract}

Keywords: Agriculture, India, Globalization, Farmers

\section{INTRODUCTION}

Globalization has had its affects in every sector of the economy. It has created a Domino effect all over the world. In Agriculture sector, which contributes to the $18 \%$ of GDP, globalization has led to introduction of new seeds, fertilizers instead of manures, new technologies instead of the old ones, but at the same time it has also led to the creation of unemployment due to the same. With Introduction of new fertilizers, it has led to reduced fertility of soil and more usage of water. This also has led to a decrease in the groundwater. Farmers with less than two hectares of land are known as Small Farmers. They account for $86.2 \%$ of all farmer in India, but own just $47.3 \%$ of the crop area, according to the 2015-16 consensus. The semi-medium and medium land holding farmers owning between 2-10 hectares of land account for $13.2 \%$ of all farmers but own $43.6 \%$ of crop area.

Implementation of the World Bank sponsored Training and Visit System was adopted by many states in 1974, which also increased the financial and human resources in the country. Vocational 


\section{International Journal of Social Science and Economic Research}

ISSN: $2455-8834$

Volume: 05, Issue: 07 "July 2020"

training has no doubt helped the farmers to maximise the growth but there was a qualitative change in 1990s, which focused on privatisation in India which led to the withdrawal of the state's support from the extension, and other non-government agencies stepped in to fill the void created. Due to Globalisation, the existing knowledge of the farmers was not enough; it was redundant.

This created supplier induced demand, due to the asymmetric knowledge between the farmers. The new reforms which were introduced brought privatisation, liberalisation and globalisation in appraisal, and led to disinvestment in the agriculture sector. The Gross Fixed Capital Formation (which measures how much of the value added is invested rather than consumed) in Agriculture, as a proportion of GDP declined from 3.1\% during 1980-85 to 1.6\% during 1997-2002.

Farmers with small land areas, after globalization were unable to compete with farmers with large amount of capital. The seeds which were provided by the state government institutions, were now open to global businesses, which led to an increase in the prices, and at the same time many farmers were also fooled by the emergence of the fake seeds which led to crop failure or less produce than expected. When output did not get along with the heavy investment made in the seeds, it led to pushing the farmers in debt trap considering that they borrowed money to invest in their production.

Even the prices of fertilizers and pesticides are so high that a small farmer can't afford and this leads to an increased investment required for the agricultural products used. The agriculture sector in India was still an infant industry when globalization was introduced, there was sudden exposure of competition when the industry was not capable to survive the global markets. The only support of the farmers was the subsidies and the regulation by the government, which was dismantled by the liberalization process in 1991, and with no proper credit system, education system, or efficient technology, the farmers have suffered majorly due to the same.

The cash crops were especially exposed to a greater price volatility because of the excess supply of the cash crops like cotton were at a much lower price because of the direct and indirect subsidies leading to the dumping by the USA and the domestic policies such as removal of the quantitative restrictions and reduction of import tariff from 35\% in 2001-02 to 5\% in 2002-03 increasing the vulnerability of the Indian Farmers to the International Prices.

Since a farmer is an unskilled labour, they can't even migrate from agricultural sector to the secondary sector in order to change their occupation, which also leaves them with a no alternative for other job opportunities, which leaves them with the last option: Loan. They don't usually have proper documentation; hence they tend to take loans from private lenders rather banks. Loans taken from private lenders often have unrealistic interest rates which a farmer 
usually fails to pay. This pressurizes them, and often results in Farmer Suicides. Farmer suicides were $12 \%$ of the total suicides in India in 2012.

\section{LITERATURE REVIEW}

Reddy (2007) presents the impacts on small farmers. Increasing inequality and shifting powers in agricultural sector are leading to some intense impacts of globalisation on small farmers both in developed and developing countries.

Globalisation includes free trade, discouragement of subsidies, enforcement of intellectual property rights and it was expected that it will bring increased employment and flexibility in matter of food security but it has resulted in decline in household subsistence, and rural demographics are changing. It has led to increased debt and use of pesticides.

Farmers growing and improving seeds for generations now face legal barriers and private companies claim they should have patent rights for creation of new "version" of the seeds. Due to the new seeds, spending on pesticides has increased by $2000 \%$ in some countries. Farmers earn less and consumers pay more which makes it more difficult for earning profit in the sector. Lack of access to overseas market to small farmers have also unfair competition from the subsidised imports rise in the supermarkets has had direct impact on local retailers hence affecting small farmers.

Lack of water and power, and weather unpredictability mostly affects the small ones. The Government spending has reduced and by statistics, developing countries only devote $7.5 \%$ of government spending to research and less than one third goes towards research. Annual foreign Aid in Agriculture in poor countries has also been gradually reduce. Privatisation has led to less reliance on extension and more on dependence on private technical consultants and this service is obviously out of reach for small farmers.

Taking the case of India, Rama Kumar (n.d.) goes through different phases of Economic growth in India after independence and discusses major policies and factors associated with the difference in the performance of the Agricultural Sector in India.

The food grain output growth in India grew at a very slow rate, two main reasons being the backward and oppressive relations of production in agriculture and independence and the problem of landlordism, but it started to pick up in the mid 1960s. In response to the fears of inadequacy of food production, Intensive agriculture development was introduced, with four main focuses- price, credit, input subsidy and marketing supports. 


\section{International Journal of Social Science and Economic Research}

Volume: 05, Issue: 07 "July 2020"

Food Corporation of India established in 1965, made sure that food was available to poor at affordable prices. Policy of nationalisation of commercial banks in 1969 also led to increase the liquidity in the rural areas, weakening the position of private moneylenders. The rate of growth of Agricultural production in the early green revolution period was lower in the early planning phase, and the benefits of the policy were unequally distributed in the different sections of the society. The low productivity region was mainly concentrated in the central region, and the higher ones were in the eastern and the southern states. The subsidy policies in the 1970s covered the pricing of inputs such as electricity for irrigation and pesticides.

In 1980s, there was a sudden boost in the Agriculture Sector. It was due to a major jump in production in the eastern region of the country, especially in the Bengal (Due to Land reforms and Decentralization) and second there was a major improvement in the production of the oilseeds (Due to The Technology Mission on Oilseeds in 1986).

1990s witnessed some major policy changes, when Liberalization was introduced into the economy. It was said the farmers would respond to the International prices and will respond by producing more. The argument was decided from a neo-classical point of view, and further it was proposed that restrictions from the internal trade and private stocks should be eliminated. Other reasons given were reduction in the public investment could be reversed by cutting down subsidies and evolution of a national market. It was also said that the food subsidies should not be universally accessible but rather targeted. The agricultural sector underwent a significant slowdown in the growth.

It was argued that Improvement of terms of trade leading to price incentives will generate a significant supply response, but the fact that to increase the production by raising prices will not produce the results if the efforts on technological fronts, inputs etc. was ignored. Many subsidies given to the farmers was withdrawn in order to 'reduce' the burden off the government, but it also made the prices of input to rise, making the poor farmers to take loans in order to be able to afford farming. Export controls were phased out and the quotas were removed. Due to the absence of all the restrictions, and ineffectiveness of the low tariffs, the increase in the imports of the crops led to a decline in the domestic prices of the crops. Decline in the prices of output, added to the problems of the farmers. Also, there was a lower demand for food grains, when the there was a surplus of food grains stocks in 1990s since the preferences were shifted to fruits, vegetables, milk products etc. also leading to reduced prices of the grain.

In earlier phases it was seen that the public and private investment complemented each and other in Indian Agriculture, but there was a shift in the trend in early 2000s, after the reforms, when private investment increased even when public investment fell. New policies also allowed 


\section{International Journal of Social Science and Economic Research}

ISSN: $2455-8834$

Volume: 05, Issue: 07 "July 2020"

private firms to cultivate on unlimited areas of land, by removing the ceiling limit, which increased the landlessness amongst the small farmers, because of increased land prices and imperfect credit markets.

Looking at the, Impact of WTO Regulations on Indian Agriculture points that the discrepancies in the trade of agricultural commodities, created by subsidies given by developed countries, made it difficult for the more competitive agriculture products from developing countries like India. This led to sacrificing survival of millions of farmers in India just for a profit of a few. A number of developed countries, continue to give large subsidies in agriculture sector, which encourage over-production leading to reduced International prices.

The agricultural reforms were based on the assumption that the increase in the terms of trade in a perfectly competitive market will be passed on to the farmers, however, evidence suggests that international agriculture market is imperfectly competitive in market.

The main theory suggests that in the export market the oligopolists, that is the MNCs, would charge a higher price than Marginal Cost while sourcing the products from the developing countries at much lower prices, than what they would have paid under perfectly competitive conditions.

India was not entitled to any safeguard mechanism, which have been used by countries which had tariffed, experienced an increase in the imports, in order to protect the domestic producers due to the increase in the imports.

The PDS system and the developmental policies with regard to Agriculture introduced by the government were not affected. The domestic support given to farmers in India was reduced significantly. Export of Horticulture products was increased, due to the increased export subsidies. Stringent Sanitary and Phytosanitary measures was also used by different countries, to reduce exports, which increased the cost of production of farmers in developing countries, such as India.

Pauline Ahoy (2016) examines the government policies that led to agrarian crisis in India. After Independence, inefficiency of the economy was visible, low foreign currency reserves which was not adequate to support import of grains even for a fortnight, inflation rose to $17 \%$, fiscal deficit were too high, and foreign investors lost confidence in Indian Economy. The Oil price shock and Gulf War added to the crisis, which led India to rely on their last resort that was, credit from IMF or World Bank. 


\section{International Journal of Social Science and Economic Research}

ISSN: $2455-8834$

Volume: 05, Issue: 07 "July 2020"

Credit was made available in 1991, but on the condition that India changes its policies and programmes, and shifts from a Protectionist Economy and shift to Liberalisation, Privatisation and Globalization. This brought in many changes, including increases in the input costs of farmers and liberalisation of many sectors in Agriculture. Seed sector liberalisation not just only bring in privates sector players, but also encourages monoculture of the hybrid cash crops which required high input cost which was transferred into debts eventually. This combined with crop failure led to mismatched expectation of farmers and indebtedness.

Srijit Mishra (2007) tries to look at the agrarian crisis in India after trade liberalisation was introduced in India. Agriculture's contribution has reduced from 56\% in 1950-51 to $23 \%$ in 2005-06. India is an Agrarian Economy; majority of people are dependent on it for their livelihood. The dependence on Agriculture has in fact increased amongst the Agricultural labourers and marginal famers.

Reduced public investment, Increased input costs, reduced role of the credit institutions, Inadequate provision of water to the farmers, Output price shocks, Excessive reliance of Farmers on the external sources of credit, Introduction of New Technologies, and reduction in extension service decline together led to the Agrarian Crisis Faced right now.

Every factor has led to the suffering of the small farmers, also leading to an agrarian crisis, and the reaction of the farmers to this crisis was majorly as Suicide. Suicide being a rare event and of high incidence in a particular group indicates us to a larger socio-economic problem. Most common method of committing suicides was by consuming pesticides, the most accessible lethal toxic element, and a hospital for treating emergencies like these are far away from where they live.

Farmer with higher outstanding debt, lower assets, larger family size, lower output don't have enough resources to sustain on the agriculture-based income. According to a survey of farmers, $40 \%$ of farmers don't want to continue in the same profession but due to limited skill sets, they have to. Without the proper resource or knowledge, farmer requires more and more credit which will lead them into a debt trap, and also in a vicious cycle of poverty.

Biru and Barjpujari (n.d.) state that there has been an astonishing fall in the absorption of food grains, and decline in the average calorie intake in rural India. Government did a limited gesture which is totally inadequate to meet the crisis.

Dhas and Albert Christopher (2009) also come to the conclusion that the crisis will have adverse effects on food supply, prices of food grains, cost of living, health and nutrition, poverty, employment, labour market, land loss from agriculture and foreign exchange earnings. In sum, 


\section{International Journal of Social Science and Economic Research}

ISSN: $2455-8834$

Volume: 05, Issue: 07 "July 2020"

the agricultural crisis would be affecting a majority of the people in India and the economy as a whole in the long run.

Looking at the present times, in article, reasons why farmers are distressed (2018), it tells us that Even though the centre is allocating large funds for several schemes to boost farmer's income. Two years of successive drought $(2014,2015)$, Collapsing prices of farm commodities, failed insurance and financial support from the government, lack of water for irrigation and new technology, bad marketing of the agricultural sector, low productivity and delayed FCI reforms have all led to create a crisis the agricultural sector, and has decreased a farmer's income significantly.

The article, India's Groundwater Crisis (2015) tells us how Depleting groundwater levels is the biggest threat to rural livelihoods, agriculture and food security. Farming practices right now are very unsustainable due to depletion of groundwater levels. With the onset of green revolution and globalisation, dependence on groundwater has increased for irrigation.

Private groundwater irrigation was encouraged by giving subsidies and extending credit for irrigation equipment. Low power tariffs also led to excessive water usage, leading to a sharp fall in water table. Fall in water table led to usage of expensive deep-water equipment, which added to the debt of the farmers.

Eastern India, even though having abundant groundwater resource, continues to suffer due to lack of power supply. Lack of electricity in the East and falling groundwater table in West and South (due to abundance of electricity these areas were encouraged to grow sugarcane and paddy even though they had lower groundwater levels) is a threat to the future crop production in India.

If we take the case of North-East India, Monjita Basumatary (2020) points that Agriculture in the region is characterised by geo-physical conditions and limited horizontal expansion of cultivable land, and contribution to the economic development is negligible considering $80 \%$ of the population is involved in agricultural activities.

The problems faced by the farmers includes, Low level of knowledge amongst the farmers, subsistence agriculture, poor infrastructure, limited connectivity, small size of operational holding, high vulnerabilities of national calamities like flood, land slide etc., low utilisation of modern inputs, low per-capita income, corruption and contentment in small quantity of production.

Those who are uneducated, were at a loss when new reforms were introduced because they don't actually know the amount of the new inputs that were introduced in the market and in what 


\section{International Journal of Social Science and Economic Research}

ISSN: $2455-8834$

Volume: 05, Issue: 07 "July 2020"

quantity they have to use in order to have a good harvest. In addition to that, the geographical location is also a barrier to infrastructural development and, transport and communications too which are further supposed to enhance the agricultural productivity, making it difficult for the country to come together as a one economy, what globalisation was actually about.

If the focus is placed on Education of the farmers, by having special government institutes and courses, then existing agricultural resources could be used in applying fertilisers and manure in proper manner. Poor education system is one of the main reasons that have led to the NorthEastern region's farmers lag a lot in terms of socio-economic development, liberalisation and modernisation, leading to underdevelopment of the region.

Wilson and Tisdell (2000) tells us how continuous use of pesticides has damaged the environment, human health, agricultural production and its sustainability and has also killed the beneficial agricultural predators.

Some of the insecticides which are banned are still illegally used because they are not protected under any patent and hence are cheaper that newly invented pesticide. Pests have developed resistance to pesticides, meaning more amount of pesticide being used to prevent pests. Declining soil fertility affects productivity and increases the need to apply larger quantities of chemical inputs to maintain productivity, increasing the costs to the farmers.

Many species of flora and fauna are also affected, and the natural balance of predators and prey have been affected especially the insect world. Fish Production has declined in paddy fields by 60-75\% due to green revolution in Bangladesh. In Australia, use of insecticide on cotton crops has contaminated beef production. In USA, beef, milk and eggs have been negatively affects. Rural water supplies are also affected.

The protective gears worn by farmers while spraying insecticides and inadequate or poorly maintained, due to the inability of farmers to buy standard protective gear. Inadequate education, Genetically Modified seeds and lack of training has led to many haphazard application and overuse.

Farmers exposed to pesticides incur costs due to hospitalisation, physician consultation and selftreatment, only if they have any medical services nearby. Most of them also rely on home remedies, which are not enough, hence leading to their death.

Globalisation has encouraged the adoption of unsustainable techniques such as use of the insecticides, and these techniques increases the cost of input, increases the yield in the short-run, but in long-term, decreases the production. 


\section{International Journal of Social Science and Economic Research}

ISSN: $2455-8834$

Volume: 05, Issue: 07 "July 2020"

Srivastava, Chand and Singh (2017) examine the sources of cost escalation and has evaluated the effects of factor prices, substitution and technological effects of the production cost. It also evaluates the effects of factor prices, technological improvements on production cost.

There has been a significant change in the input-use, that is, from traditional inputs to modern inputs. It has affected the production cost and profitability of the crop enterprise. The growth of the output is not in line with the growing cost of production, leading to a downward trend in the average net returns. There is an inelastic substitution between labour and machine along with inelastic demand for labour, leads to an increase in the cost of labour utilised, hence leading to an increase in cost of production. It is not technically feasible to replace all manual farm operations with machine.

Consequence of imperfect substitution is increase in share of labour in Cost of Cultivation in the recent years, despite declining labour-use for farm operations. Therefore, it is necessary to promote efficient and appropriate farm mechanisation suitable for small farm situations.

States with low level of productivity, production cost can be reduced by improving crop yield. Controlling input prices would lead to a less than proportional increase in input use (the demand of inputs is inelastic according to the research) which will result is cost saving for the farmers. Managing human labour alone would bring a reduction in crop budget of the farmers.

The slow pace of technological improvements in Indian agriculture, shows the need to accelerate efforts to raise yield at a faster rate to offset the effects of rising cost and maintain a fair margin in crop cultivation.

Looking at the production and export, V. Mallika (2012) examines the effects of globalisation on production of exports India. The export-import policies were extremely liberalised, custom duties and subsidies drastically lowered, agricultural investment was reduced, the restructuring of the PDS system really affected the availability of food grains. All such measures had the effect on the farm sector. The agricultural share also substantially declined because of development of secondary and tertiary sectors.

With increased economic efficiency and diversified production base, the share of agricultural goods in total exports has fallen. Liberal import of Agricultural products that is crash prices of agricultural products especially of cash crops was due to lowering of the import duties and on the other hand cutback in agricultural subsidies led to increased input prices. Creation of Special Economic zones, that is taking for of land by the government of industrial purposes also led to acquirement of fertile lands, which deprived the farmers of their lands. 


\section{International Journal of Social Science and Economic Research}

ISSN: 2455-8834

Volume: 05, Issue: 07 "July 2020"

K. Nagaraj and P. Sainath (2014) examines the secondary data that are available on farmers' suicides in the country, the magnitude and trends of the farmers' suicides in India and the regional patterns, in the incidence and the trends in these suicides. It is believed that the main reason for these suicides is the Agrarian crisis, but assigning a unique, mono causal explanation to it doesn't do justice to it.

The definition of farmer according to the police is the one who had title to land, leading to a faulty report. Even Women farmers for that instance, are not counted properly because of the Gender stereotype or the fact that since the male member is the bread earner of the house, he will be the one owning the land. About $85 \%$ of total suicides of farmers were male and rest all female.

Some specific years that is, 1998, 2002 and 2004 showed an increase in the farm suicides. Looking at the states with highest farm suicides, Maharashtra, Andhra Pradesh, Chhattisgarh and Madhya Pradesh from 2001 to 2011 were on the top. These states are also the ones that are facing acute agrarian crisis, which is deeper than any other state in India. The reason for this could be the pre-existing condition of very high vulnerability in the region, absence of alternate livelihoods, no good linkage to the rural-urban cities are one of the many factors that can account for this.

Other reasons for farmer's suicides include high input costs, sudden decline in economic/social position, indebtedness etc. Also, after the policy reforms decline in the public investments, increased participation of the foreign MNCs, Banking Sector reforms, external trade liberalisation were the reasons for the same.

The relief programmes given by the government doesn't really help the farmers in the long term, but just helps them in short term. All the reasons point towards the fact that there is an agrarian crisis prevailing in India which needs immediate attention and action.

Muralidhar, Mamatha, Jayakumar, and Mary (2015) analyse the negative impacts of globalisation with specific focus on Andhra Pradesh and how it led to increase in Suicide in the state.

Higher prices for the food-grain in the market did not result in increase in the average income of a common man. The Crisis in Andhra Pradesh, was held by Chandrababu Naidu, who was then the Chief Minister of Andhra Pradesh and pursued Liberalisation with enthusiasm. He even had the first-ever state level agreement with the World bank, agreeing to a "structural-adjustment" Loan. 


\section{International Journal of Social Science and Economic Research}

ISSN: $2455-8834$

Volume: 05, Issue: 07 "July 2020"

The country previously had access to seeds from the state government, APSSDC, in case of Andhra Pradesh, but most of them were shut down after liberalisation. India's seed market was open to global agri-businesses like Monsanto, and this led to a hike in the price of the seeds. Yields are very less than promised, and the amount of insecticides and pesticides used is very high, and everything pushes the farmer to debt. Also, the subsidies on pesticides were removed.

Electricity prices were also increased because previously, the crops didn't require that much of electricity, and subsidised electricity was a success but the companies started to face losses after globalisation due to the increase in production of cash crops, and hence increased the tariff. Andhra Pradesh being drought prone, worsened the situation.

Another problem was devaluation of rupees by $25 \%$, which made Indian crops very cheap and hence the was a sudden price decline of the crops. By 2001, India completely removed the restrictions on import of almost 1500 items including food encouraging the subsidised imports into the country. Increased cotton supply in the market reduced the cotton prices by $60 \%$ in 1995 , and same happened with pepper where the prices declined heavily due to $0 \%$ import duty. This led to increased suicides amongst the farmers, amongst which most of them in Maharashtra were from cotton producing belt till 2003, of which $70 \%$ of the farmers were cultivating BT Cotton, a genetically modified seed that yielded a much lower produce than promised by Monsanto and from the pepper producing districts in Kerala.

In article Seeds of suicide: How Monsanto Destroys Farming (2013) presents how Monsanto, an agrochemical company, which promised to bring good produces by conserving more, came into India after liberalisation policy adopted by India which was imposed by the world bank.

When Monsanto came into picture, seeds which farmers common resources became the intellectual property of Monsanto, which was shown by the patents filed by the company. Open pollinated seeds were displaced by the hybrids, including the GMO hybrids. A renewable resource became non-renewable patented commodity.

Cotton now could not be mixed with different crops, and had do be grown in Monoculture with high risks to pests and diseases, which increased the amount of insecticide and fertilisers that had to be used thus increasing the input cost of the farmers.

The seed monopoly of the company, destruction of the alternatives, collection of super-profit in the form of royalties, and increasing vulnerabilities of monoculture has created a context for debt and suicides in India. 


\section{International Journal of Social Science and Economic Research}

ISSN: $2455-8834$

Volume: 05, Issue: 07 "July 2020"

In these two could put break in the BT cotton story(2018), an article by Economic times, it was briefed that Maharashtra is the state with largest area under cultivation and the sudden increase in the pink bollworm infestation has raised questions about the sustainability of the Genetically Modified crops, which accounts for $90 \%$ of all cotton grown and were introduced during Globalization.

Other types of Genetically Modified crops are not legal in India, and the productivity is expected to be 9\% lower in 2017-18, even though the area for cultivation is bigger. Pink Bollworm is affecting the production the most, and Monsanto is to be blamed for that because it is the failure of the technology for which they charge a fee.

Besides the problem of pink bollworm, the production is also plagued by use of illegal herbicidetolerant Bt cotton seed. Farmers don't really have any alternative to use any other seeds, hence the current problems faced by them are an anomaly.

Patil (2014) briefs about the different trajectories of Indian Agricultural Crisis and how it has worsened over the past few years. It points out that the agricultural deterioration started with the rule of British, when they introduced the new land system, which laid a foundation for capitalism in the agricultural sector. It created an unbalance situation, which led to under-development of agricultural sector. It was followed on by land reforms, which was mostly in favour of the landowning class and after that green revolution, which brought in a new technology in India for agricultural sector, but only helped the landed class rather than the poor peasantry.

The 1990s reforms laid the further foundation for the present agrarian crisis in India. Impact of British Rule, Failure of Government Policies and Programmes, Natural Factors such as drought and rainfall, misplace priorities of government, sharp increase in agricultural costs, Unremunerative Prices, Wrong Fragmentation and sub-division of land, Impact of liberalisation and Land acquisition by the government for public purposes laid the framework for the crisis.

Agricultural sector needs to be protected from the volatilities of both domestic and international market, and other effects of liberalisation. The sector requires state support given the nature of the socio-economic conditions of the peasants in the country. There should be a remunerative price for agricultural commodities by having appropriate pro-farmers policies. HYV seeds should be promoted along with the know-how about how to use them. Land reforms should also be reconsidered. Small-scale agro-based industry should be promoted, and more youth which are not agriculture should be educated. 
Agriculture in India is a base for growth for Indian economy, hence it is important there is a sustained growth in the agricultural sector in order to promote a stronger bas for overall growth of the economy.

Dev (2008) presents the problems India will face in order to overcome the Agricultural Crisis. In recent years, it is seen that the performance of the agricultural sector has declined. Low yield growth and increased input prices are one of the reasons for the same.

The total factor productivity, was low in the agricultural sector than other sectors. Post-reform TFP increased marginally in the non-agricultural sector as compared to the agricultural sectors.Regional disparities have increased in the country, income inequality between small, marginal farmers and average farmers is much greater and farmer's suicide rate have also risen at the same time.

Price policies on various considerations such as changes in input price and input-output price parity, Pro-agriculture macro-policies, Land reforms, subsidies and investments and rural infrastructure are very important for the agricultural growth. Improved irrigation systems, water management, Diversification in crops by maintaining food security, Marketing of the Agricultural Sector should also be done.

In order to do so district planning should be done, Institutional reforms should be brought in and Institutions for sustainable land and water management should be specially employed in the rural agricultural sector.

\section{RESEARCH GAP}

Climate change, which leads to poor productivity of crops is not taken into account while considering the reasons for agrarian crisis in India. Increased industrialisation, leads to emission of various kinds of greenhouse gases, which acts as a major contributor to climate change. India's total GHG emissions in 2014 were around 6.55\% of the world average. None of the paper takes into account how climate change affects the productivity and how it is related to Globalisation.

Food insecurity should also be considered to measure the agrarian crisis going on in the country. It is important to address the linkages between the agricultural productivity and food Insecurity. Globalisation, has led to decline in production of small and marginalised farmers, leading to less income for them leading to food insecurity. 


\section{International Journal of Social Science and Economic Research}

ISSN: $2455-8834$

Volume: 05, Issue: 07 "July 2020"

Lack of transparency and delay of the recognition of the ongoing agrarian crisis in the country from the Indian government from even though continuation of suicides by thousands of farmers all over the country should also be considered as a factor as one of the factors worsening the situation.

There is a huge discrepancy between the data of Central Statistical organisation and Ministry of Agriculture. The research papers lack analysing the discrepancies of data. The discrepancies could have been caused by changes of the base year of Gross Value of Output which happen frequently at different intervals and according to that the weights attached to different crops also changes. These discrepancies manipulate the data and hence errors in further research.

\section{RESEARCH QUESTION}

1) Has the globalisation in Agricultural sector in other countries led to the same agrarian crisis as in India? If not, why?

Objective: To compare and contrast between the agricultural sectors of different country with India and study that if the other parts of world are facing similar crisis, why is that the globalisation is encouraged in agricultural sector and if they are not facing the crisis, what went wrong in India which led to this problem.

\section{SCOPE FOR FURTHER STUDIES}

After comparison with different countries, once we know how the policies could have been implemented in a different way, the government and the farmers can work on those aspects leading to betterment of the Agricultural sector and the economy as a whole. This will lead to formulation of better policies for the sector by the government, hence leading to better living standards for the poor.

\section{CONCLUSION}

Globalisation has affected farmers all over the world. Corporate globalisation has affected the rural communities in several ways, and the same impacts can be seen in the case of India. Indian Agriculture still continues to affect more than half of the population and the steps taken to improve the sector, has become the cause of the ongoing crisis in the country. The green revolution of the country helped farmers to improve the productivity, but that was totally based on government support, which included, subsidies, price support, credit support and above all the knowledge support. 
The reforms of 1991, was against the institutional changes in agriculture, rather it was said that opening the Indian Economy to trade will reduce the problems that is faced by the sector in order to increase the agricultural surplus. The reforms weakened the state support provided to the farmers, import tariffs were removed, due to fiscal reforms major subsidies were removed, leading to a high increase in the cost of input and fall in the prices of many commodities leading to a price shock, especially to the small farmers. The public capital in the agricultural sector was reduced and the government regulated markets were treated as a hinderance to the efficient markets.

Not only the state support was removed, globalisation has also led to the destruction of the environment and at the same time, has affected the mental and physical health of the farmers across the country. This has also resulted in the surge of the suicides of the farmers, due to the same.

If the Neo-liberal policies, especially in agricultural sector are reversed, it will be of huge relief to the small farmers. The 'few' reliefs packages given by government, is just a myopic solution of the situation and the impact will not be reduced until and unless some bold steps are taken by the government to make the post-reform agrarian scenario in India a success.

\section{REFERENCES}

Ahoy, P. (2016, December). Agrarian Crisis India: An Aftermath of the New Economic Reforms. $\quad$ Retrieved from $\mathrm{Nd}$ Publishers: http://ndpublisher.in/admin/issues/IJSSAv1n1i.pdf

B.V. Muralidhar, D. M. (2015, June 30). Globalization and Its Impact on Indian Agriculture: A Study of Farmers' Suicides in the State of Andhra Pradesh. Retrieved from Scribd: https://www.scribd.com/document/270103805/Globalization-and-Effects-on-Indian-Agri

Basumatary, M. (2020, January). Education, Globalization and Status of Agricultural Development in NE India . Retrieved from IJRTE: https://www.ijrte.org/wpcontent/uploads/papers/v8i5/E4578018520.pdf

Birendra Kr., B. I. (n.d.). JAN SUNWAI ON THE PRESENT AGRARIAN CRISIS A REPORT. Retrieved from Gene Campaign: https://genecampaign.org/wpcontent/uploads/2014/07/THE_AGRARIAN_CRISIS_IN_INDIA.pdf

Clevo Wilson, C. T. (2000, November). WHY FARMERS CONTINUE TO USE PESTICIDES DESPITE ENVIRONMENTAL, HEALTH AND SUSTAINABILITY COSTS. 
International Journal of Social Science and Economic Research

ISSN: $2455-8834$

Volume: 05, Issue: 07 "July 2020"

Retrieved from Research Gate: https://www.researchgate.net/publication/4840284_Why_Farmers_Continue_to_Use_Pes ticides_Despite_Environmental_Health_and_Sustainability_Costs

Dev, S. M. (2008, May 2). Challenges for Revival of Indian Agriculture . Retrieved from NCAP: http://www.ncap.res.in/upload_files/jml/jml1.pdf

Dhas, A. C. (2000, November 30). Agricultural Crisis in India: The Root Cause and Consequences . Retrieved from MPRA: https://mpra.ub.uni-muenchen.de/18930/

Gupta, S. (2018, December 13). 10 reasons why farmers are in distress. Retrieved from Times of India: $\quad$ https://timesofindia.indiatimes.com/india/10-reasons-why-farmers-are-indistress/articleshow/67069814.cms

Hosamane, M. D. (2019, March 04). Globalisation-induced neglect of farm sector must end Retrieved from Deccan Herald: https://www.deccanherald.com/opinion/panorama/globalisation-induced-neglect$\underline{721536 . h t m l}$

Impact of WTO Regulations on Indian Agriculture. (n.d.). Retrieved from Shodh Ganga: https://shodhganga.inflibnet.ac.in/bitstream/10603/108024/11/11_chapter\%203.pdf

K. Nagaraj, P. S. (2014, January). Farmers' Suicides in India: Magnitudes, Trends, and Spatial Patterns, 1997-2012. Retrieved from Research Gate: https://www.researchgate.net/publication/275659698_Farmers\%27_Suicides_in_India_M agnitudes_Trends_and_Spatial_Patterns_1997-2012

Mallika, V. (2012). Agrarian Crisis in India: It's Impact on Production and Export. Retrieved from Semantic Scholar: https://www.semanticscholar.org/paper/Agrarian-Crisis-inIndia\%3A-It's-Impact-on-ProductionMallika/281699d2dea1c2eeba6fe5d16c2c8e3e9d6b60fa\#paper-header

Mishra, S. (2007, January). Agrarian Scenario in Post-reform India: A Story of Distress, Despair and Death. Retrieved from Research Gate: https://www.researchgate.net/publication/23799688_Agrarian_scenario_in_postreform_India_A_Story_of_distress_despair_and_death

R.B.Patil, D. (2014, February). Agrarian Crises in Contemporary India: Some Sociological Reflections. Retrieved from World Wide Journals: 
International Journal of Social Science and Economic Research

ISSN: 2455-8834

Volume: 05, Issue: 07 "July 2020"

https://www.worldwidejournals.com/paripex/recent_issues_pdf/2014/February/February 2014_1393595378_2cd81_04.pdf

RAMAKUMAR, R. (n.d.). INDIAN AGRICULTURE UNDER ECONOMIC REFORMS: A PRELIMINARY REVIEW. Retrieved from Network Ideas: http://networkideas.org/ideasact/jan09/PDF/Ramakumar.pdf

Reddy, D. D. (2007, June 18). Impact of Globalization on Small Farmers Worldwide: Implications on Information Transfer. Retrieved from IFLA: https://archive.ifla.org/IV/ifla73/papers/120-Reddy-en.pdf

S.K. Srivastava, R. C. (2017). Changing Crop Production Cost in India: Input Prices, Substitution and Technological Effects. Retrieved from Semantics Scholar: https://www.semanticscholar.org/paper/Changing-Crop-Production-Cost-in-India\%3AInput-and-Srivastava-Chand/429e8965a4aa2bb8e3ede866b97215ab7d71d30f

Seetharaman, G. (2018, January 21). These two issues could put the brakes on the Bt cotton story. Retrieved from Economic Times: https://economictimes.indiatimes.com/news/economy/agriculture/the-brakes-are-appliedon-the-bt-cotton-story/articleshow/62583116.cms

Shiva, D. V. (2013, April 5). The Seeds Of Suicide: How Monsanto Destroys Farming. Retrieved from Global Research: https://www.globalresearch.ca/the-seeds-of-suicide-howmonsanto-destroys-farming/5329947

Singh, P. (2015, May 1). India's groundwater crisis. Retrieved from Mint: https://www.livemint.com/Opinion/v4nXpXNxSJtxQNIEbvtJFL/Indias-groundwatercrisis.html 